\title{
Penerapan Peraturan dan Prosedur Kelas Dalam Membentuk Sikap Disiplin Siswa Kelas 1 Sekolah Dasar
}

\author{
Nita Aprianda Siahaan 1 , Year Rezeki Patricia Tantu ${ }^{2 *}$ \\ ${ }^{1}$ Sekolah Dian Harapan Manado, Indonesia \\ ${ }^{2}$ Universitas Pelita Harapan, Indonesia \\ *Coresponding Author: year.tantu@uph.edu
}

Article History:

Received 2021-11-18

Revised 2021-12-23

Accepted 2022-01-17

DOI:

10.31949/educatio.v8i1.1682

\begin{abstract}
The discipline attitude for grade 1 primary school students needs to be continuously formed and developed. During online learning, it was found that there were still many students who joined late, spoke when the teacher explained, did not submit assignments, and did not follow online class procedures. In the end, learning becomes less conducive. One of method to shape student discipline is to apply classroom rules and procedures. The research objective is to describe the application of classroom rules and procedures in shaping the disciplined attitude of 1 st grade primary school students. This study uses a qualitative descriptive method based on the results of teacher and peer observations, as well as teacher reflection. The results found indicate that the application of classroom rules and procedures can form students' discipline. The application of these classroom rules and procedures provides direction that helps students understand the actions that should be taken during learning so that students can follow the established classroom rules and procedures. This research can still be carried out with a longer time and adjustment of rules and procedures to class conditions and the development of primary school students.
\end{abstract}

Keywords: discipline; rules; procedures; primary school student

\section{PENDAHULUAN}

Disiplin merupakan sikap yang dibutuhkan sekaligus dikembangkan dalam proses pembelajaran. Menurut Sutrisno (2009), disiplin adalah suatu kontrol individu terhadap perilakunya dengan usaha memilih yang baik berdasarkan pengaruh pihak luar ataupun merupakan keinginannya sendiri. Novitasari (2019) menyatakan bahwa memiliki sikap disiplin pada siswa mampu membuat anak menjadi terkontrol yang pada akhirnya membuat anak memiliki kemampuan mengendalikan diri yang baik. Melihat hal tersebut, sikap 
disiplin penting untung dikembangkan sejak dini sehingga anak-anak dapat melatih kemampuan pengendalian diri lebih baik.

Berdasarkan hasil observasi di salah satu sekolah di Kupang, ditemukan bahwa siswa kelas 1 SD masih kurang menunjukkan sikap disiplin selama pembelajaran daring. Sehubungan dengan kondisi pandemi, proses pembelajaran masih berlangsung tatap maya melalui Ms. Teams. Selama proses pembelajaran, masih ada siswa yang terlambat join Ms. Teams, menekan icon microphone dan langsung berbicara ketika guru menjelaskan, makan saat pembelajaran berlangsung, tidak memakai seragam lengkap, serta beberapa siswa tidak mengumpulkan tugas. Perilaku yang ditunjukkan merujuk kepada kurangnya sikap disiplin yang dimiliki dalam diri siswa. Hal ini ditelaah berdasarkan dengan pendapat Garmo (2013) yang menyatakan bahwa secara umum kedisiplinan pada seseorang akan ditampilkan melalui keteraturan, ketepatan waktu, sikap hemat dan pintar mengelola berbagai sumber untuk mencapai tujuan. Sejalan dengan itu, Hudaya (2018) juga menyatakan bahwa indikator disiplin adalah hadir tepat waktu, menyelesaikan tugas tepat waktu, mengikuti aturan kelas, bersikap jujur dan aktif selama proses pembelajaran. Ketika siswa tidak menaati peraturan, pembelajaran menjadi kurang kondusif karena suara guru menjadi tidak terdengar saat anak tidak mengangkat tangan atau tidak memohon izin terlebih dahulu untuk bertanya. Dampak selanjutnya adalah siswa kurang memahami materi dan instruksi tugas dari guru karena siswa melakukan kegiatan lain saat pembelajaran berlangsung.

Hurlock dalam buku Psikologi Perkembangan mengatakan bahwa siswa yang duduk di kelas 1 SD tergolong pada siswa yang berada pada tahap akhir masa kanak-kanak. Pada tahapan ini, pada umumnya anak melakukan pelanggaran di sekolah disebabkan oleh ketidaktahuan akan apa yang diharapkan dari padanya atau karena salah mengerti peraturan. Oleh karena itu, dalam mengatasi permasalahan yang muncul, guru perlu menerapkan peraturan dan prosedur kelas sesuai dengan perkembangan anak agar anak mampu memahami peraturan dengan baik. Slameto (2020) menyatakan peraturan merupakan kesepakatan antara guru dan siswa di dalam kelas yang menjadi patokan dalam mengelola setiap tindakan di dalam kelas disertai adanya konsekuensi. Pembuatan peraturan kelas harus diiringi dengan pembuatan prosedur kelas. Denti (2012) memaparkan bahwa prosedur kelas merupakan cara untuk mengatasi perilaku siswa dengan memberikan arahan perilaku di dalam kelas. Dengan memberikan peraturan dan prosedur kelas yang sesuai dengan tahap perkembangan anak diharapkan dapat membantu pembentukan sikap disiplin dalam diri anak.

Adapun langkah-langkah pembuatan peraturan dan prosedur kelas yaitu menetapkan tujuan, kemudian memberitahu kepada anak daftar peraturan dan prosedur beserta konsekuensinya (DePorter, Reardon, \& Singer-Nourie, 2010). Dalam memberikan konsekuensi, guru perlu mengidentifikasi konsekuensi terhadap pelanggaran aturan secara tepat sesuai dengan perkembangan anak. Konsekuensi bukan bertujuan membuat siswa takut melainkan menolong siswa memperbaiki tindakannya untuk mencapai pembentukan sikap disiplin hingga terbentuk karakter yang baik (Graham, 2009). Lebih lanjut, Bahman dan Maffin (2008) menyatakan bahwa peraturan dan prosedur harus disampaikan dengan kalimat positif seperti ajakan bukan larangan, serta perlu berulang-ulang disampaikan supaya siswa memahami secara jelas. Selain itu, peraturan dan prosedur kelas perlu dibuat dengan bahasa lebih sederhana yang dapat dimengerti oleh siswa Sekolah Dasar. Dengan demikian, dalam membuat peraturan dan prosedur kelas perlu ada rencana dan penyampaian yang baik sehingga siswa memahami tujuan, daftar aturan dan prosedur serta konsekuensinya.

Penelitian terbaru masih menyatakan bahwa penerapan peraturan dan prosedur kelas masih efektif dipakai sebagai salah satu cara dalam mendisiplinkan siswa. Annisa (2019) mengatakan bahwa aturan berperan penting dalam mendorong terbentuknya sikap disiplin dan membantu siswa memahami tindakan yang benar dan tidak. Kemudian, Siregar (2017) juga menyatakan pengelolaan perilaku siswa di dalam kelas dapat dilakukan dengan menerapkan peraturan serta prosedur kelas. Hal ini juga didukung oleh Prima (2016) yang menyatakan bahwa penerapan prosedur dan peraturan kelas yang disertai konsekuensi dan reward mampu membuat kedisiplinan siswa meningkat. Berdasarkan temuan-temuan yang ada, sikap disiplin siswa dapat dibentuk melalui penerapan peraturan dan prosedur kelas yang dilakukan guru. Penerapan peraturan dan prosedur kelas ini akan menolong siswa memahami batasan dalam berperilaku sehingga guru dapat mengelola perilaku siswa di dalam kelas yang pada akhirnya membentuk sikap disiplin pada siswa. 
Dalam memecahkan permasalahan kedisiplinan siswa, sangat penting memahami bahwa guru memiliki otoritas dalam membimbing dan mengarahkan siswa agar menjadi pribadi yang disiplin. Efendi dan Gustriani (2019) menyatakan bahwa guru selama pembelajaran berupaya menciptakan pembelajaran yang efektif melalui pengelolaan perilaku dengan penetapan peraturan dan prosedur kelas hingga membentuk sikap disiplin siswa. Sari dan Hadijah (2017) melalui penelitiannya menemukan bahwa semakin efektif pengelolaan guru, maka sikap disiplin siswa selama pembelajaran semakin terbentuk. Hal ini berarti penerapan peraturan dan prosedur kelas dipengaruhi oleh peran guru dalam kelas ketika menjelaskan peraturan dan prosedur yang disepakati. Guru berperan untuk menuntun siswa dalam perkembangan moralnya melalui pengarahan dan pembimbingan dengan penuh kasih sehingga siswa bisa memahami dan taat terhadap aturan yang ditetapkan. Guru perlu memberi tanggapan yang tepat terhadap perilaku yang ditunjukkan oleh siswa dalam kelas, baik itu berupa penghargaan maupun konsekuensi.

Berdasarkan paparan di atas, rumusan masalah yang diangkat dalam artikel ini adalah bagaimana penerapan peraturan dan prosedur di dalam kelas dalam membentuk sikap disiplin siswa kelas 1 SD? Dalam menjawab rumusan masalah ini, adapun yang menjadi tujuan penelitian adalah mengkaji penerapan peraturan dan prosedur kelas dalam membentuk sikap disiplin siswa kelas 1 SD.

\section{METODE PENELITIAN}

Metode penelitian yang digunakan adalah penelitian deskriptif kualitatif. Penelitian dilakukan dengan melihat fenomena yang terjadi di sebuah kelas saat pembelajaran berlangsung, kemudian fenomena dijelaskan secara deskriptif berdasarkan data-data kualitatif yang diambil selama pembelajaran. Penelitian dilakukan di salah satu sekolah dasar swasta yang berada di daerah Kupang pada tanggal 20 Juli 2020 sampai 28 Agustus 2020. Adapun subjek penelitian adalah siswa kelas 1 Sekolah Dasar sebanyak 27 siswa.

Prosedur penelitian yang dilakukan adalah 1) Observasi; 2) Identifikasi Masalah; 3) Penerapan Solusi; dan 4) Evaluasi. Pada tahap observasi, peneliti melakukan observasi selama pembelajaran pada siswa kelas 1 SD. Kemudian, peneliti melakukan identifikasi masalah yang terjadi di kelas dengan memperhatikan indikator dari teori sehingga menemukan bahwa masalah yang terjadi adalah kurangnya sikap disiplin siswa selama pembelajaran. Setelah itu, peneliti mengeksplorasi metode yang dapat membantu siswa menjadi lebih disiplin. Peneliti kemudian mendapatkan bahwa hal mendasar yang dapat membantu siswa kelas 1 SD adalah penerapan peraturan dan prosedur kelas yang sesuai dengan tahapan perkembangan usia anak SD. Kemudian, peneliti merancang instrumen penelitian dengan menyusun indikator-indikator yang dinilai. Peneliti menerapkan metode ini selama tujuh kali mengajar. Setelah itu, peneliti melakukan evaluasi terhadap pembelajaran yang berlangsung.

Instrumen yang digunakan selama penelitian adalah lembar observasi untuk melihat perilaku siswa dalam kelas selama mengikuti pembelajaran daring, lembar umpan balik untuk melihat pengelolaan kelas yang dilakukan oleh guru, dan refleksi peneliti sebagai pendukung dalam melihat ketercapaian solusi yang diberikan serta catatan lain yang perlu diperhatikan selama pembelajaran berlangsung. Adapun teknik analisis data yang digunakan adalah analisis secara kualitatif, yaitu dimulai dengan mengumpulkan data, mereduksi data atau mengambil poin-poin penting terkait variabel penelitian, menyajikan data-data yang penting, dan mengambil kesimpulan.

\section{HASIL DAN PEMBAHASAN}

Pembentukan sikap disiplin pada siswa kelas 1 SD menjadi perhatian dalam penelitian ini karena bertujuan mendorong siswa melatih pengendalian diri sehingga siswa dapat memiliki kontrol diri yang baik dan dapat berperilaku taat. Hal ini tentu dapat berdampak baik bagi diri siswa sendiri maupun bagi komunitas kelas. Tujuan dari disiplin bagi anak tidak hanya sebatas membuatnya mematuhi aturan, melainkan mendorong anak memiliki sikap tanggung jawab akan dirinya dan orang lain (Mulyadi, 2004). Sikap disiplin dapat menolong anak dapat hidup bermasyarakat dengan baik kelak nanti. 
Penerapan peraturan dan prosedur kelas yang bertujuan membentuk sikap disiplin siswa dilakukan selama tujuh kali mengajar. Langkah-langkah yang dilakukan, ialah yang pertama mendiskusikan mengenai daftar peraturan dan prosedur kelas dengan rekan sejawat. Peraturan umum kelas daring yang disepakati berupa hadir melalui Ms. Teams tepat waktu, menyalakan kamera, memakai seragam lengkap, tidak menekan icon mute pada seseorang yang sedang berbicara, tidak mengeluarkan sesamanya dari room meeting, dan tepat waktu mengumpulkan tugas sesuai instruksi. Adapun yang menjadi prosedur kelas adalah selama guru menjelaskan siswa harus dalam kondisi mute, kemudian saat ingin berbicara/bertanya dapat menekan icon raise hand dan menunggu guru mempersilakan. Peraturan yang disepakati ini disesuaikan dengan proses pembelajaran daring oleh siswa dengan menggunakan aplikasi Ms. Teams. Kedua, guru menetapkan konsekuensi sesuai dengan perkembangan usia anak. Konsekuensi yang diterapkan ialah waktu khusus berbicara secara personal dengan guru saat melakukan pelanggaran terlambat. Kemudian, siswa diminta mengerjakan tugas kembali saat tidak mengumpulkan tugas atau mengerjakan tugas tidak sesuai dengan instruksi. Pemberian konsekuensi bertujuan supaya siswa bukan hanya sekedar mamahami kesalahannya, namun siswa diberikan kesempatan untuk memperbaiki kesalahannya. Konsekuensi ini dipilih sebagai konsekuensi yang tidak melanggar hak-hak siswa dan tidak membuat siswa takut, tetapi mengarahkan siswa mendapat pemahaman yang benar mengenai hal penting yang perlu dilakukan. Hal ini didukung oleh pernyataan Graham (2009) yang menyatakan bahwa konsekuensi bukan bertujuan membuat siswa takut melainkan menolong siswa memperbaiki tindakannya untuk mencapai pembentukan karakter yang diinginkan. Ketiga, guru menjelaskan peraturan dan prosedur kepada siswa. Peraturan dan prosedur kelas ini masih tergolong baru bagi siswa karena siswa masih dalam tahap adaptasi dalam proses pembelajaran daring, sehingga penting untuk menjelaskan kepada siswa tujuan dan konsekuensinya. Setelah itu, guru juga mengajak siswa untuk menyetujui peraturan dan prosedur kelas yang sudah dijelaskan dalam bentuk mengajar siswa berjanji melakukan peraturan dan prosedur kelas tersebut. Hal ini dilakukan sebagai langkah awal melibatkan siswa dalam proses penerapan peraturan dan prosedur kelas. Keempat, guru mengajak siswa melakukan simulasi dalam menerapkan prosedur kelas. Dimulai dengan mengajak siswa secara bersama-sama untuk mempraktikkan penggunaan fitur kamera, microphone, dan raise hand dikarenakan masih banyak siswa yang belum dapat menggunakan fitur dengan baik.

Selama menerapkan peraturan dan prosedur kelas sebanyak tujuh kali pembelajaran, terlihat pada minggu pertama masih banyak siswa yang masih melakukan pelangaran terhadap peraturan dan prosedur yang disepakati. Saat ada pelanggaran, langkah berikut yang dilakukan adalah guru memberikan konsekuensi dengan menegur dan mengarahkan siswa, serta meminta siswa mengumpulkan kembali tugas yang tidak dikumpulkan dan tidak sesuai dengan instruksi. Dalam hal prosedur, guru meminta siswa untuk mengulangi prosedur yang disepakati. Di sisi lain, guru memberikan reward berupa pujian kepada siswa yang mengikuti peraturan dan prosedur kelas. Selama proses mengajar, guru selalu berusaha konsisten dalam menerapkan peraturan dan prosedur kelas. Hal ini bertujuan untuk mendorong siswa memahami akan pentingnya mengikuti aturan dan prosedur di dalam kelas.

Berdasarkan observasi, penerapan peraturan dan prosedur kelas membawa dampak positif pada sikap disiplin siswa. Hal ini dapat dilihat dari berkurangnya siswa yang melakukan pelanggaran. Data hasil observasi pada sikap disiplin siswa pada awal hingga akhir penerapan peraturan dan prosedur kelas dapat dilihat pada tabel 1. Berdasarkan tabel 1, terlihat bahwa belum semua siswa dapat mengikuti peraturan dan prosedur yang ditetapkan guru. Tidak bisa dipungkiri bahwa pembentukan sikap disiplin memang memerlukan waktu, pembiasaan, dan bimbingan oleh guru sehingga siswa-siswa kelas 1 Sekolah Dasar dapat memahami peraturan dan prosedur yang sedang dijalankan. Saat melihat siswa-siswa yang masih melanggar prosedur dalam kelas, guru menegur dan mengarahkan siswa. Guru perlu terus mengingatkan siswa mengenai prosedur yang harus dijalankan agar kelas berlangsung kondusif. Setelah menerima teguran, siswa meresponi dengan baik dan menunjukkan perilaku disiplin. Saat terjadi pelanggaran terhadap aturan, guru memberikan konsekuensi kepada siswa, yaitu mengerjakan kembali tugas yang tidak dikumpulkan dan guru berbicara secara personal kepada siswa.

Open Access: https://ejournal.unma.ac.id/index.php/educatio 
Tabel 1. Hasil Observasi Awal Indikator Sikap Disiplin

\begin{tabular}{|c|c|c|c|}
\hline Indikator & $\begin{array}{c}\text { Skala } 3 \\
\text { Semua siswa mengikuti } \\
\text { dengan baik }\end{array}$ & $\begin{array}{l}\text { Skala } 2 \\
\text { Ada } 2-5 \text { siswa tidak } \\
\text { mengikuti }\end{array}$ & $\begin{array}{l}\text { Skala } 1 \\
\text { Lebih dari } 5 \\
\text { siswa tidak } \\
\text { mengikuti }\end{array}$ \\
\hline Datang tepat waktu & & $\sqrt{ }$ & \\
\hline Mengerjakan setiap tugas dari guru & & & $\sqrt{ }$ \\
\hline $\begin{array}{l}\text { Menekan mute microphone saat guru sedang } \\
\text { menjelaskan dan raise hand apabila hendak } \\
\text { berbicara }\end{array}$ & & & $\sqrt{ }$ \\
\hline Tidak mengeluarkan teman dari room meeting & & $\sqrt{ }$ & \\
\hline
\end{tabular}

Guru menegur siswa dengan menggunakan kalimat yang santun dan tidak melukai perasaan siswa. Van Brummelen (2009) mengatakan bahwa guru harus memiliki kasih dalam membimbing siswa. Guru juga memberikan pujian kepada siswa yang sudah mengikuti peraturan dan prosedur kelas sehingga siswa bisa mempertahankan perilaku disiplin yang sudah ditunjukkan selama pembelajaran.

Tabel 2. Hasil Observasi Akhir Indikator Sikap Disiplin

\begin{tabular}{lccc}
\hline \multicolumn{1}{c}{ Indikator } & $\begin{array}{c}\text { Skala 3 } \\
\text { Semua siswa mengikuti } \\
\text { dengan baik }\end{array}$ & $\begin{array}{c}\text { Skala 2 } \\
\text { Ada 2-5 siswa tidak } \\
\text { mengikuti }\end{array}$ & $\begin{array}{c}\text { Sebala 1 } \\
\text { siswa tari 5 } \\
\text { mengikuti }\end{array}$ \\
\hline $\begin{array}{l}\text { Datang tepat waktu } \\
\text { Mengerjakan setiap tugas dari guru }\end{array}$ & $\sqrt{ }$ \\
$\begin{array}{l}\text { Menekan mute microphone saat guru sedang } \\
\text { menjelaskan dan raise hand apabila hendak } \\
\text { berbicara }\end{array}$ & $\sqrt{ }$ & \\
Tidak mengeluarkan teman dari room meeting & $\sqrt{ }$ & \\
\hline
\end{tabular}

Pada akhir pembelajaran, berdasarkan tabel 2, terlihat bahwa ada peningkatan pada indikator sikap disiplin yang ditunjukkan siswa. Semua siswa sudah memahami dan mengikuti prosedur berbicara dengan menekan fitur raise hand apabila bertanya dan menekan fitur mute ketika guru menjelaskan sehingga tidak membuat keributan dan tidak mengganggu proses pembelajaran yang sedang berlangsung. Selain itu, selama proses pembelajaran, tidak ada siswa yang mengeluarkan teman dari ruangan virtual. Melalui penerapan peraturan dan prosedur kelas, terlihat bahwa komunitas dalam kelas menjadi semakin baik. Dengan menunjukkan sikap disiplin, siswa mengharagai guru dan sesamanya. Guru pun menghargai siswa yang sudah berusaha melakukan yang terbaik dalam menaati peraturan dan prosedur kelas. Namun, masih terlihat masih ada 2-5 siswa yang masih tidak datang tepat waktu saat pembelajaran daring dan tidak mengerjakan tugas dari guru. Guru perlu terus konsisten dalam memberikan konsekuensi kepada siswa-siswa yang belum mengikuti aturan. Guru juga dapat melibatkan orang tua dalam memantau dan membimbing siswa agar bisa menaati peraturan dan prosedur yang sudah disepakati.

Melihat temuan ini, penerapan peraturan dan prosedur kelas yang dilakukan sesuai dengan langkahlangkah yang sistematis dan konsisten mampu mengarahkan siswa untuk lebih bersikap disiplin selama pembelajaran daring. Hasil penelitian ini sejalan dengan penelitian dari Lumbantoruan, Widiastuti, Tangkin (2021) yang menyatakan bahwa penerapan peraturan dan konsekuensi yang didukung pemberian konsekuensi logis, nasihat dan motivasi dapat meningkatkan kedisiplinan siswa lebih dari 50\%. Penelitian lain menyatakan bahwa penerapan penghargaan dan konsekuensi dengan mempertahankan kekonsistenan dalam penerapannya dan disertai dengan penggunaan bahasa non-verbal dapat meningkatkan kedisiplinan siswa (Gultom \& Siahaan, 2016). Sebuah temuan dari Sanjaya \& Panggabean (2021) juga menyatakan bahwa peningkatan disiplin dalam kelas yang diajar dapat terjadi setelah guru menerapkan aturan yang sederhana, memberi tahu alasan pemberian aturan, menciptakan konsekuensi yang masuk akal, dan menjelaskan aturan dan prosedur serta konsekurnsi dengan jelas. Hal ini menjadi penting untuk dicatat oleh setiap pendidik bahwa peningkatan 
sikap disiplin siswa hanya bisa dilihat ketika guru mempersiapkan dengan baik peraturan dan prosedur yang akan diberikan serta menerapkannya dengan konsisten.

Berdasarkan umpan balik dari rekan guru, tercatat bahwa guru harus memberi perhatian kepada semua siswa, bukan hanya terhadap siswa yang tidak melakukan prosedur tetapi juga kepada siswa yang sudah melakukan peraturan dan prosedur, seperti menekan fitur raise hand saat ingin berbicara agar semua siswa dapat ditanggapi dengan tepat. Selain itu, guru juga perlu terus menekankan mengenai tujuan dari penerapan peraturan dan prosedur sebagai bentuk sikap menghargai sesama. Peran guru dalam melihat keunikan setiap siswa juga menjadi terasah melalui penelitian ini. Sebagai peneliti, guru bukanlah pribadi yang sudah sempurna dalam mengelola kelas, tetapi terus-menerus mengevaluasi diri dalam melakukan manajemen kelas sehingga pembelajaran dapat menjadi lebih baik. Terlihat bahwa guru menunjukkan perubahan pada bagian pengelolaan kelas, dalam hal cara menegur, memuji, dan pemberian konsekuensi kepada siswa.

Hal penting yang perlu ditekankan adalah guru perlu terus membantu siswa memahami bahwa aturan dan prosedur bukan untuk membatasi melainkan menolong siswa memahami tindakan yang benar selama pembelajaran. Hal ini dilakukan secara terus-menerus dengan menjelaskan dari tujuan penerapannya. Dengan demikian, pembentukan sikap disiplin siswa terjadi berdasarkan kesadaran siswa terhadap pentingnya menghargai sesama bukan sekedar karena rasa takut terhadap konsekuensi. Sikap disiplin yang terbentuk atas pembaharuan nilai dalam diri siswa tidak akan hilang melainkan terus-menerus berkembang secara positif. Pada akhirnya sikap disiplin pada diri siswa akan membuat siswa memiliki kemampuan kontrol diri yang baik hingga akhirnya siswa terdorong memiliki karakter yang benar.

\section{KESIMPULAN}

Berdasarkan hasil penelitian yang dipaparkan, penerapan peraturan dan prosedur kelas dapat membantu pembentukkan sikap disiplin siswa. Penerapan peraturan dan prosedur harus memperhatikan langkah-langkah, seperti membuat daftar peraturan, prosedur, dan konsekuensi yang akan diterapkan, menjelaskan peraturan kepada siswa dengan bahasa yang sederhana, melakukan simulasi prosedur belajar daring kepada siswa, mengajak siswa untuk terlibat menyetujui peraturan dan prosedur yang ada, memberikan penghargaan bagi siswa yang sudah melakukan, dan memberikan konsekuensi bagi siswa yang masih menunjukkan perilaku kurang disiplin. Peraturan dan prosedur kelas berguna memberikan siswa batasan dalam berperilaku di kelas. Hal ini juga mendorong siswa belajar tunduk akan otoritas di atasnya. Dalam penerapannya, guru harus dapat secara konsisten menegakkan setiap aturan dan prosedur kelas. Hal ini supaya siswa semakin taat terhadap aturan dan prosedur kelas yang berlaku sehingga sikap disiplin siswa akan terus berkembang.

Penelitian dapat dilakukan dengan waktu yang lebih panjang untuk melihat efektivitas dari penerapan peraturan dan prosedur kelas kepada siswa sekolah dasar lebih detail. Peraturan dan prosedur yang diterapkan juga perlu disesuaikan dengan kondisi kelasnya dan kondisi perkembangan siswa sekolah dasar sehingga bisa lebih optimal.

\section{DAFTAR PUSTAKA}

Annisa, F. (2019). Penanaman nilai-nilai pendidikan karakter disiplin pada siswa Sekolah Dasar. Perspektif Pendidikan Dan Keguruan, 10(1), 69-74.

Bahman, S., \& Maffini, H. (2008). Developing children's emotional intelligence. London: Continuum International Publishing Group.

Denti, L. G. (2012). Proactive classroom management: A practical guide to empower students and teachers. United States of America: CORWINS A SAGE Company.

DePorter, B., Reardon, M., \& Singer-Nourie, S. (2010). Quantum Teaching: Mempraktikkan Quantum Learning Di Ruang-Ruang Kelas. Bandung: Kaifa.

Efendi, R., \& Gustriani, D. (2019). Manajemen kelas di sekolah dasar. Pasuruan: CV. Penerbit Qiara Media. 
Garmo, J. (2013). Pengembangan karakter untuk anak: Panduan pendidik. Jakarta: Kesaint Blanc.

Graham, D. L. (2009). Teaching Redemptively: Bringing Grace and Truth into Your Classroom. Colorado Springs, CO : Purposeful Design Publications.

Gultom, L., \& Siahaan, M. F. (2016). Penerapan reward dan konsekuensi untuk meningkatkan kedisiplinan siswa kelas II SD sekolah Kristen ABC. Jurnal Polyglot, 12 (2), 101-116. DOI: http://dx.doi.org/10.19166/pji.v12i2.368

Hudaya, A. (2018). Pengaruh gadget terhadap sikap disiplin dan minat belajar peserta didik. Research and Development Journal of Educaion, 4(2), 86-97. DOI:10.30998/rdje.v4i2.3380

Hurlock, E. B. (2012). Psikologi Perkembangan, Suatu Pendekatan Sepanjang Rentang Kehidupan (terjemahan). Jakarta: Erlangga.

Lumbantoruan, L., Widiastuti, \& Tangkin, W. P. (2021). Penerapan Rules and Procedures Untuk Meningkatkan Kedisiplinan Siswa. Jurnal Educatio, 7(2), 546-553. DOI: 10.31949/educatio.v7i2.1084

Mulyadi, S. (2004). Seri cerdas emosi: Membantu anak balita mengelola amarahnya. Jakarta: Erlangga for Kids.

Novitasari, A. (2019). Pemberian reward and punishment dalam membentuk karakter disiplin anak pada sekolah madrasah ibtidaiyah. Halaqa: Islamic Education Journal, 3(1), 27-33. DOI:10.21070/halaqa.v3i1.2113

Prima, E. (2016). Metode reward dan punishment dalam mendisiplinkan siswa kelas IV di Sekolah Lentera Harapan Gunung Sitoli Nias. JEPUN: Jurnal Pendidikan Universitas Dhyana Putra, 1(2), 185-198.

Sanjaya, H., \& Panggabean, M. (2021). Implementasi Prosedur, Peraturan dan Konsekuensi Kelas Untuk Meningkatkan Kedisiplinan Siswa Kelas 8. Scholaria: Jurnal Pendidikan Dan Kebudayaan, 11(1), 63-71. https://doi.org/10.24246/i.js.2021.v11.11.p63-71

Sari, B. P., \& Hadijah, H. S. (2017). Meningkatkan disiplin belajar siswa melalui manajemen kelas. Jurnal Pendidikan Manajemen Perkantoran, 2(2), 233-241. DOI:10.17509/ipm.v2i2.8113

Siregar, A. H. (2017). Membela guru pada masa tiga mendikbud: Dari Mohammad Nuh, Anies Baswedan bingga Muhadjir Effendy. Yogyakarta: Deepublish.

Slameto. (2020). Strategi implementasi manajemen berbasis sekolah (MBS) dengan profesional. Pasuruan: CV Qiara Media.

Sutrisno, H. (2009). Kasus perilaku pelanggaran disiplin siswa di sekolah ditinjau dari kerangka teori sosiologi fungsionalisme. Jurnal Pendidikan Inovatif, 4(2), 60-66.

Van Brummelen, H. (2009). Berjalan dengan Tuhan di dalam kelas. Tangerang: UPH Press. 